\title{
Engineering the $\beta$-ketoacyl-acyl carrier protein synthase gene in the synthesis of cell wall mycolic acids in Mycobacterium neoaurum for enhancing the bioconversion of steroidal intermediates from phytosterols
}

\section{Liang-Bin Xiong}

Shanghai University of Medicine and Health Sciences

\section{Hao-Hao Liu}

East China University of Science and Technology

Ming Zhao

East China University of Science and Technology

Yong-Jun Liu

East China University of Science and Technology

\section{Lu Song}

East China University of Science and Technology

\section{Zhi-Yong Xie}

East China University of Science and Technology

Yi-Xin Xu

Shanghai University of Medicine and Health Sciences

Feng-Qing Wang ( $\nabla$ fqwang@ecust.edu.cn )

East China University of Science and Technology https://orcid.org/0000-0002-3473-5991

Dong-Zhi Wei

East China University of Science and Technology

\section{Research}

Keywords: Mycolic acids, Self-enhancement conversion, $\beta$-Ketoacyl-acyl carrier protein synthase, Phytosterol, Steroid intermediates

Posted Date: December 20th, 2019

DOI: https://doi.org/10.21203/rs.2.19378/v1 
License: (c) (i) This work is licensed under a Creative Commons Attribution 4.0 International License. Read Full License

Version of Record: A version of this preprint was published at Microbial Cell Factories on March 30th, 2020. See the published version at https://doi.org/10.1186/s12934-020-01335-y. 


\section{Abstract}

Background: The bioconversion of phytosterols into high value-added steroidal intermediates is the cornerstone in steroid pharmaceutical industry. However, the low transportation efficiency of hydrophobic substrates into mycobacterial cells severely limits the transformation. In this study, a robust and stable modification of the cell wall strikingly enhanced the cell permeability for the high production of steroids.

Results: The interference of the nonessential $\beta$-ketoacyl-acyl carrier protein synthase KasB resulted in a disturbed proportion and a shortened length of mycolic acids (MAs), thus leading to a remarkable improvement of cell permeability. The yield of $9 a$-hydroxy-4-androstene-3,17-dione (9-OHAD) was increased by $137.7 \%$ in the vegetative cell transformation. Ultimately, the 9-OHAD productivity in an industrial used resting cell system was reached $0.1135 \mathrm{~g} / \mathrm{L} / \mathrm{h}(10.9 \mathrm{~g} / \mathrm{L}$ 9-OHAD from $20 \mathrm{~g} / \mathrm{L}$ phytosterol) and the conversion time was shortened by $33 \%$. In addition, a similar self-enhancement effect (34.5\%) was realized in the 22-hydroxy-23,24-bisnorchol-4-ene-3-one (4-HBC) producing strain.

Conclusions: The modification of $k a s B$ resulted in a meaningful change in the cell wall mycolic acids. Deletion of the $k a s B$ gene remarkably improved the cell permeability, leading to a self-enhancement of the steroidal intermediate conversion. The results showed a high efficiency and feasibility of this construction strategy.

\section{Background}

Steroidal drugs are the second largest category in the pharmaceutical market. More than 400 kinds of steroid drugs for a wide range of diseases are selling with an annual sale of 100 billion dollars [1]. Modifying the mycobacterial metabolic pathway for accumulating high value-added steroid intermediates is the most important step of the latest upgraded semi-synthetic route in steroidal pharmaceutical industry [2]. By the conversion of low value-added phytosterols, environment friendly extracts from the vegetable oil processing waste, sustainable pine tree bioresource and waste products in papermaking [3], C19 steroids (androst-4-ene-3,17-dione, AD; boldenone, BD; 9a-hydroxy-androst-4-ene3,17-dione, 9-OHAD) [4, 5] and C22 steroids (22-hydroxy-23,24-bisnorchol-4-ene-3-one, 4-HBC) [6] can be respectively accumulated. Then, almost all kinds of steroid drugs, including adrenocortical and progestational hormones, can be produced by the combinational chemical modifications [7]. For instance, 9-OHAD is a core intermediate and has been used as a cost-effective precursor to synthesize C21 adrenocortical hormone drugs [7]. However, the unsatisfying yield and productivity of the currently used strains has prompted researchers to intensively investigate more efficient and stable strategies for the biosynthesis of important steroidal intermediates $[8,9]$.

Sterols can be catabolized as the sole carbon and energy source for maintaining the balance of basic physiological metabolism in mycobacteria [8]. The uptake of sterols in cells may be divided into two distinguished stages: (I) the mass transfer stage of sterol molecules and particles to cell surface and (II) the diffusion stage of sterols across the cell wall and membrane. Stage I is mainly depends on the direct 
contact with the substrates dispersed in the extracellular environment. Early studies on material transfers demonstrated that in the presence of hydroxypropyl- $\beta$-cyclodextrin [10], the use of biocompatible waterimmiscible organic phase [11] could largely improve the solubilization of sterol substrates in the transformation system. As a result, the cells contacted with the sterols more efficiently. The substrate transfer was enhanced and the conversion productivity was increased accordingly. In addition, the $\beta$ cyclodextrin possibly improved the permeability due to the alteration of mycobacterial cell wall structure [12]. Thus, with the addition of glycine and vancomycin, which were inhibitors to the synthesis of mycobacterial cell wall, the cell permeability displayed a marked improvement [13]. However, these strategies employing massive additives are seldom used in the industrial process because of the high costs and low effects. It is noteworthy that most of the aforementioned methods possibly lead to some defects of the cell wall. The mycobacteria cell wall contains extremely rich mycolic acids [14]. This component accounts for $40 \%-60 \%$ of the cell dry weight and are probably responsible for the crucial cell permeability characteristic $[15,16]$. Rational modifications of the mycolic acid biosynthesis pathway might be reasonable ways to alter the permeability performance of the steroidal conversion microbial cell factories.

Mycolic acids are synthesized originally from acetyl-CoA and malonyl-CoA (Fig. 1a) [17]. The C16-C18 and C24-C26 a-alkyl chain is elongated based on Claisen condensation catalyzed by the fatty acid synthase I (FAS-I). The resulting short chain is synthesized by $\beta$-ketoacyl-ACP synthases (FabH) to form $\beta$-ketoacyl-ACP. Then, a long mero chain can be obtained by the repetitive reductive cycles due to the catalysis of multienzyme fatty acid synthase II complex (FAS-II). Additional elongation cycles are subsequently catalyzed by the two $\beta$-ketoacyl-ACP synthase KasA and KasB. After the mero-chain and achain are coupled together by the acyl-AMP ligase FadD32 and the polyketide synthase Pks13 and then deoxidized by the mycolate reductase $\mathrm{CmrA}$, the mature mycolate (trehalose monomycolate, $\mathrm{TMM}$ ) can be synthetized in the mycobacterial cytoplasm. Next, the TMM is transported to the cell periplasm and participates in the subsequent assembly of mycolic acid-related structures, including the polar TDM and mycolic acid methyl esters in the core mycolyl-arabinogalactan-peptidoglycan (MAMEs-AG-PG) complex of cell wall [16]. The FAS-I synthesis gene fas is required in M. smegmatis [18] and M. tuberculosis [19] and the fatty acid synthase II (FASII) enzymes InhA [20], MabA [21], HadB [22], and KasA [23] are also required. The inactivation of these indispensable genes could lead to the lysis of mycobacterial cells [2023]. The disruption of nonessential genes possibly caused some stable defects only in the cell wall. Thus, the loss of the dispensable genes, such as hadA, hadC and kasB in the mero-mycolic acid synthesis pathway, are worth investigation in the model steroid transformation cells $[15,17]$.

The biotransformation process is a rate-limiting step in the microbes producing steroid intermediates. It usually takes 120 to $144 \mathrm{~h}$ to realize a satisfactory conversion rate of the substrate to target steroid intermediates in the microbes $[4,5,24]$. However, it only takes about 48 to $72 \mathrm{~h}$ in most of other prokaryotic microorganisms [25-27]. The long conversion time is primarily attributed to the low permeability of sterol substrates into the cell wall [28]. Promoting the substrate to enter microbial cells by modifying the cell wall may shorten the time required by the bioconversion process and improve the integral production capacity of mycobacterial cells. 
Increasing the sterol biotransformation efficiency in M. neoaurum through a systemic cell wall engineering technique was rarely reported [28]. The disruption of the genes involved in mycolic acid synthesis in mycobacterial cells was not directly assessed. In the study, the annotated nonessential mycolic acid synthetic genes were inactivated individually. The modification which significantly altered the sterol conversion was further investigated. The result revealed the roles of accessory genes in the formation of mycolic acids and provided an alternative evolution strategy for the microbial transformation of steroidal intermediates.

\section{Methods}

\section{Strains, plasmids and primers}

All strains used in this study are described below (Table 1). Escherichia coli DH5a (TIANGEN Biotech. Co., Ltd., Shanghai, China) was used for plasmid amplification. The wild type M. neoaurum ATCC 25795 (Mn) was purchased from American Type Culture Collection (ATCC). The C19 steroidal intermediate 9-OHAD producer $\mathrm{Mn} \Delta k s t D 1 \Delta k s t D 2 \Delta k s t D 3(\mathrm{WI})$ was constructed by Kang Yao [5]. The $\mathrm{C} 22$ steroidal intermediate 4-HBC-producing strain Mn $\Delta k s h A \Delta h s d 4 A \Delta k s t D 1 \Delta k s t D 2 \Delta k s t D 3$ (WIII) was constructed by Li-Qin Xu [6]. Others were all derived from the above three $M$. neoaurum strains. Common plasmids (Additional file 1: Table S1) and primers (Additional file 1: Table S2) were used for constructing the mutants.

\section{Media and culture conditions}

Media and culture conditions were the same as the previously described conditions $[28,29]$. E. coli DH5a was inoculated at $37^{\circ} \mathrm{C}$ in $5 \mathrm{~mL}$ of Luria-Bertani (LB) medium. Kanamycin (50 mg/L) or hygromycin (100 $\mathrm{mg} / \mathrm{L}$ ) was added to the culture medium as required. Mycobacterial strains were firstly cultivated in $5 \mathrm{~mL}$ of LB until OD600 was between 1.2 and 1.8. Then, according to an inoculum volume ratio of 1:10 (v/v), the cell suspension was inoculated into $30 \mathrm{~mL}$ of MYC/01 medium $(20.0 \mathrm{~g} / \mathrm{L}$ glycerol, $2.0 \mathrm{~g} / \mathrm{L}$ citric acid,

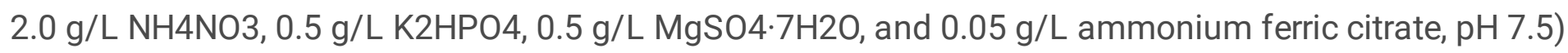
in 250-mL flasks to obtain the mycobacterial seed suspension (OD600 $=1.2-1.8)$.

For phenotypic identification, according to an inoculum volume ratio of $1: 10(\mathrm{v} / \mathrm{v})$, the cultivated cells were then transferred into $30 \mathrm{~mL}$ of minimal medium (MM) $\left(2.0 \mathrm{~g} / \mathrm{L} \mathrm{NH}_{4} \mathrm{NO}_{3}, 0.5 \mathrm{~g} / \mathrm{L} \mathrm{K}_{2} \mathrm{HPO}_{4}, 0.5 \mathrm{~g} / \mathrm{L}\right.$ $\mathrm{MgSO}_{4} \cdot 7 \mathrm{H}_{2} \mathrm{O}$, and $0.05 \mathrm{~g} / \mathrm{L}$ ammonium ferric citrate) with $1 \mathrm{~g} / \mathrm{L}$ glycerol or $1 \mathrm{~g} / \mathrm{L}$ cholesterol (purity > $95.0 \%$, Adamas Reagent, Ltd., Shanghai, China). Cells were harvested by the centrifugation at $4,000 \mathrm{~g}$ for 10 min.

For the bioconversion in growth cells, according to an inoculum volume ratio of 1:10 (v/v), the cultivated seed cells were inoculated into $30 \mathrm{~mL}$ of MYC/02 medium $(10.0 \mathrm{~g} / \mathrm{L}$ glucose, $2.0 \mathrm{~g} / \mathrm{L}$ citric acid, $2.0 \mathrm{~g} / \mathrm{L}$ $\mathrm{NH}_{4} \mathrm{NO}_{3}, 0.5 \mathrm{~g} / \mathrm{L} \mathrm{MgSO}{ }_{4} \cdot 7 \mathrm{H}_{2} \mathrm{O}$, and $0.05 \mathrm{~g} / \mathrm{L}$ ferric ammonium citrate, $\mathrm{pH} 7.5$ ) with $5 \mathrm{~g} / \mathrm{L}$ phytosterols (purity $>95.0 \%$, every $100 \mathrm{~g}$ of phytosterol contained $47.5 \mathrm{~g}$ of $\beta$-sitosterol, $26.4 \mathrm{~g}$ of campesterol, $17.7 \mathrm{~g}$ of stigmasterol, $3.6 \mathrm{~g}$ of brassicasterol and $4.8 \mathrm{~g}$ of undetermined components) (Zhejiang Davi Pharmaceutical Co., Ltd., Zhejiang, China) [29]. Cholesterol (100.0 g/L) and phytosterol (100.0 g/L) was 
emulsified in Tween $80(5 \% \mathrm{w} / \mathrm{v})$ aqueous solution at $121^{\circ} \mathrm{C}$ for $60 \mathrm{~min}$ before use. The shake flask experiments of $M$. neoaurum strain were carried out at $30^{\circ} \mathrm{C}$ and $200 \mathrm{rpm}$.

For resting cell conversion, according to an inoculum volume ratio of 1:10 (v/v), the cultivated cells were transferred into $150 \mathrm{~mL}$ of MYC/02 medium in 1000-mL shake flasks for the growth at $30{ }^{\circ} \mathrm{C}$ and 200 $\mathrm{rpm}$. The cells were harvested by the centrifugation at 8,000 $\mathrm{g}$ for $15 \mathrm{~min}$, washed with $20 \mathrm{mM} \mathrm{KH}_{2} \mathrm{PO}_{4}$, and diluted into $200 \mathrm{~g} / \mathrm{L}$ of cell suspensions. The subsequent conversion step was performed in $250-\mathrm{mL}$ flasks containing $100 \mathrm{~g} / \mathrm{L}$ mycobacterial cells, $20 \mathrm{~g} / \mathrm{L}$ phytosterols and $80 \mathrm{~g} / \mathrm{L}$ hydroxypropyl- $\beta$ cyclodextrin (HP- $\beta-C D$, RSC Chemical Industries Co., Ltd., Jiangsu, China) in at $30^{\circ} \mathrm{C}$ and $200 \mathrm{rpm}$ [30]. Standard 9-OHAD (99\%) was purchased from J\&K Scientific Ltd. (Beijing, China). Standard reference 4HBC (97\%) was purified and identified by ourselves [6].

\section{Construction of genetically modified strains}

Target gene-deleted strains were obtained through allelic homologous recombination in mycobacteria as previously described [31]. p2NIL and pGOAL19 were used for the construction of the homologous recombination plasmids (Additional file 1: Table S1). The knockout-plasmids p19-gene was transferred into mycobacterial cells via electroporation.

To complement the deficient-gene function, the complete gene sequence was firstly amplified from the wild type strain and then inserted into the pMV261 to create a recombinant pMV261-gene plasmid, which could be used to overexpress the carried gene in multiple copies. Moreover, the expression cassette of the target gene containing a heat shock promoter $h s p 60$ was obtained from the recombinant p261-gene through double-digestion and then integrated into the pMV306 to create a complemental plasmid p306gene. The constructed plasmid p306-gene could be integrated into chromosomal DNA in single copy to complement the disrupted gene function.

\section{Analysis of cell permeability and steroid uptake performance}

The permeability change of cell envelope was estimated by measuring the fluorescence intensity of cells labeled by fluorescein diacetate (FDA, Aladdin Reagents (Shanghai) Co., Ltd., Shanghai, China) according to previous procedures with some minor amendments [32]. The cells were suspended in $4.5 \mathrm{~mL}$ of phosphate buffer (cell density reached 106 cells $/ \mathrm{mL}$ ), mixed with $0.5 \mathrm{~mL}$ of FDA acetone solution (2 $\mathrm{mg} / \mathrm{mL}$ ) and then vibrated at $32{ }^{\circ} \mathrm{C}$ for $10 \mathrm{~min}$ before the detection with a Fluoroskan Ascent fluorescence spectrophotometer (Thermo Labsystems Inc., PA, USA). Maximum excitation wavelength for the detection was $485 \mathrm{~nm}$, and the emission wavelength was $538 \mathrm{~nm}$.

The quantity of cholest-4-en-3-one (purity $>95.0 \%$, Shanghai TITAN Scientific Co., Ltd., China) entering mycobacterial cells per unit time was determined to check for the cell permeability change. This steroid was emulsified in Tween $80(5 \% \mathrm{w} / \mathrm{v})$ aqueous solution at $121^{\circ} \mathrm{C}$ for $60 \mathrm{~min}$ in advance for use. The cultivated cells were inoculated into $30 \mathrm{~mL}$ of MYC/02 medium with $1.0 \mathrm{~g} / \mathrm{L}$ cholest-4-en-3-one. After 12 -h growth, $5 \mathrm{~mL}$ of culture solution was sampled, centrifuged at $12,000 \mathrm{~g}$ for $10 \mathrm{~min}$, washed with $1.0 \mathrm{~mL}$ of 
$\mathrm{ddH}_{2} \mathrm{O}$ for two times, and then washed with $1.0 \mathrm{~mL}$ of the mixture of petroleum ether and ethyl acetate $(6: 4, v / v)$ to remove the cholest-4-en-3-one from the media. The cells $(50 \mathrm{mg}$, wet weight) were then suspended in $1.0 \mathrm{~mL}$ of the mixture of acetonitrile and $\mathrm{ddH}_{2} \mathrm{O}(7: 3, \mathrm{v} / \mathrm{v})$. Then, $0.8 \mathrm{~g}$ of glass beads were added in the suspension. The cells were destroyed with FastPrep-24 instrument (MP Biomedicals, CA, USA) and centrifuged at 12,000 $\mathrm{g}$ for $10 \mathrm{~min}$. Cholest-4-en-3-one entering cells could be released and dissolved in acetonitrile. The extracts were analyzed with a reversed-phase C18-column $(250 \mathrm{~mm} \times 4.6$ $\mathrm{mm})$ at $254 \mathrm{~nm}$ with the Agilent 1100 series HPLC system. The mixture of methanol and water $(8: 2, \mathrm{v} / \mathrm{v})$ was used as the mobile phase.

\section{Analysis of mycolic acid methyl esters (MAMEs)}

The MAMEs were extracted and analyzed as previously described [16, 28, 33]. Briefly, $50 \mathrm{mg}$ (in wet weight) of mycobacterial cells were collected at $12,000 \mathrm{~g}$ for $10 \mathrm{~min}$. After adding $0.5 \mathrm{~mL}$ of the mixture of methanol and chloroform $(2: 1, \mathrm{v} / \mathrm{v})$, the homogenized mixture was incubated at $60^{\circ} \mathrm{C}$ for $2 \mathrm{~h}$ and centrifuged at 12,000 $\mathrm{g}$ for $10 \mathrm{~min}$. The polar lipids including TMM and TDM were dissolved in the supernatant.

Next, $500 \mu \mathrm{L}$ of $10 \%$ tetrabutylammonium hydroxide (Sigma-Aldrich LLC., MO, USA) was added to the above defatted cells or $50 \mathrm{mg}$ of whole cells and heated at $100{ }^{\circ} \mathrm{C}$ overnight. After cooling, $500 \mu \mathrm{L}$ of $\mathrm{ddH}_{2} \mathrm{O}, 250 \mu \mathrm{L}$ of dichloromethane, and $62.5 \mu \mathrm{L}$ of iodomethane (Sigma-Aldrich LLC., MO, USA) were added into the mixture. Then, the diluted mixture was stirred for $30 \mathrm{~min}$ and centrifuged at $12,000 \mathrm{~g}$ for 10 min to remove the upper layer. The lower organic layer was washed with $1.0 \mathrm{~mL}$ of $1 \mathrm{M}$ hydrochloric acid, followed by $1.0 \mathrm{~mL}$ of $\mathrm{ddH}_{2} \mathrm{O}$. The reaction solution was dried under a stream of nitrogen. The residue was dissolved in a mixture of toluene $(0.2 \mathrm{~mL})$ and acetonitrile $(0.1 \mathrm{~mL})$, followed by the addition of acetonitrile $(0.2 \mathrm{~mL})$ for $1-\mathrm{h}$ incubation at $4{ }^{\circ} \mathrm{C}$. The MAMEs were centrifuged at $12,000 \mathrm{~g}$ for $10 \mathrm{~min}$ and then re-suspended in $200 \mu \mathrm{L}$ of dichlormethane.

The extracted mycolic acids were analyzed by silica gel TLC plates in a solvent system (chloroform: methanol, 90:10, v/v). The keto-MA spots on preparative silica gel TLC were purified for MALDI-TOF-MS (Xevo G2, Waters, Ltd., MA) analysis as described [15].

\section{Sterol bioconversion and the extraction and analysis of steroidal intermediates}

Both vegetative cells and resting cells were determined to assess the sterol conversion capability [28, 30]. Firstly, the vegetative cell biotransformation medium $(0.5 \mathrm{~mL})$ was extracted with the same volume of ethyl acetate. Then the sample containing steroidal intermediates from resting cell transformation system was extracted with ten times of volume of ethyl acetate.

A gas chromatography (GC) system 7820A (Agilent Technologies, CA, USA) was used for the quantitative determination of cholesterol and phytosterols. The ethyl acetate extracts $(5 \mu \mathrm{L})$ were injected into a DB-5 column (30 m $\times 0.25 \mathrm{~mm}$ (i.d.) $\times 0.25 \mu \mathrm{m}$ film thickness, Agilent Technologies, CA, USA). The oven temperature was programmed as follows: $200^{\circ} \mathrm{C}$ for $2 \mathrm{~min}, 200^{\circ} \mathrm{C}$ to $280^{\circ} \mathrm{C}$ within 4 min, $280{ }^{\circ} \mathrm{C}$ for 2 
$\min , 280^{\circ} \mathrm{C}$ to $305^{\circ} \mathrm{C}$ within $1.5 \mathrm{~min}$, and $305^{\circ} \mathrm{C}$ for $10 \mathrm{~min}$. Inlet and flame-ionization detector temperatures were maintained at $320^{\circ} \mathrm{C}$. Nitrogen carrier gas flow was $2 \mathrm{~mL} / \mathrm{min}$ at $50^{\circ} \mathrm{C}$.

A 1100 series high-performance liquid chromatography system (HPLC) (Agilent Technologies, CA, USA) was employed to analyze the extracts containing steroidal intermediates. The prepared samples were analyzed with a reversed-phase C18-column $(250 \mathrm{~mm} \times 4.6 \mathrm{~mm})$ (Agilent Technologies, CA, USA) at 254 $\mathrm{nm}$. The mixture of methanol and water $(8: 2, \mathrm{v} / \mathrm{v})$ was used as the mobile phase.

\section{Results And Discussion}

\section{Disruption of the mycolic acid synthesis genes disturbed the sterol conversion}

Mycolic acids, as the main cell wall constituent, are generally synthesized in the cytoplasm (Fig. 1a) [16, 17]. The interference with the nonessential gene, such as the (3R)-hydroxyacyl-ACP dehydratase hadA and methyl mycolic acid synthase $1 \mathrm{mmaA1}$, etc., involved in the synthesis of mycolic acids might reduce the tightness of cell wall and lead to a stable change in cell permeability. For further studies, the genes involved in the synthesis of mycolic acids were preliminarily evaluated by the comparative transcriptome analysis between the wild type strain and its primary derivative 9-OHAD-producing strain (Mn $\Delta k s t D 1)$ [31]. The transcription of the annotated genes showed discrete variations, revealing that the mycolic acid synthesis might not be dramatically disturbed during the bioconversion of sterols (Fig. 1b, Additional file 1: Table S3).

Next, some dispensable genes were screened through the targeted deletion of the mycolic acid synthesis pathway. Interestingly, the inactivation of most of the accessary genes resulted in a slight alteration of sterol conversion rate in all the strains except the kasB-deleted strain (Fig. 1C). As expected, the deletion of the gene remarkably increased the sterol conversion by $143 \%$ at the $72-h$ sampling time. Early studies demonstrated that the $k a s B$ was a nonessential gene responsible for the extension to full-length meromycolic acids in $M$. tuberculosis. The loss of the gene caused the synthesis of shorter mycolates [15], indicating that a meaningful permeability change might occur in the mutant strain.

\section{Functional KasB maintained the cell permeability and the balance of steroid uptake in $M$. neoaurum}

The possible kasB genome region in M. neoaurum ATCC 25795 (GenBank Accession No. NZ_JMDW00000000.1) was re-confirmed by comparing the homologous regions in Mycobacterium tuberculosis H37Rv (GenBank Accession No. NC_000962), Mycobacterium smegmatis mc2 155 (GenBank Accession No. NC_008596) and Mycobacterium neoaurum VKM Ac-1815D (GenBank Accession No. CP006936.2). The kasB gene (GeneBank: NZ_JMDW01000013.1; Region: 177334... 178587, 1254-bp) in M. neoaurum shared high sequence identity with its homologs (Additional file 2: Fig. S1), indicating its conserved function in mycobacteria. In addition, the flanking genes of kasB also had the similar frame. These results proved that the annotation and position of the $k a s B$ gene was correct (Additional file 2: Fig. S1; Additional file 1: Table S4). The allelic homologous recombination was employed to delete the kasB cassette in the wild type M. neoaurum. A 1171-bp upstream sequence and 
1111-bp downstream sequence were amplified to construct the plasmid vector for gene knockout (Additional file 2: Fig. S2). PCR and electrophoresis analysis results of the kasB region in genomic DNA confirmed the occurrence of allelic replacement in M. neoaurum (Fig. 2a).

In mycobacteria, kasA and kasB encode two distinct fatty acid synthase II complexes. KasA is responsible for the initial elongation of mycolic acids less than 40 carbons, whereas KasB is involved in the extension from 40 carbons to 54 carbons [17]. The $M n \triangle k a s B$ mutant strain and the complemented strain $M n \triangle k a s B+k a s B$ were generated for subsequent experiments. The deletion of $k a s B$ led to an obvious alteration of cell growth in the presence of cholesterol and the $\mathrm{Mn} \triangle \mathrm{kas} B$ strain growth was much faster than that of its parental wild type strain and the complemented strain (Fig. 2b). Subsequently, the permeability of $k a s B$-deficient strain was assessed through determining the fluorescence intensity of the cells after labeling with fluorescein diacetate (FDA). The Mn $\Delta k a s B$ mutant strain had the more permeable cell wall. This wild type property could be restored in the mutant strain upon the introduction of the complete functional kasB gene (Fig. 2c). To further confirm this, the analog of cholesterol, cholest-4-en-3one was employed as a label to check for the cell permeability to steroids [28]. The analysis indicated that the improved the cell wall permeability indeed resulted in a significant enhancement in the uptake of cholest-4-en-3-one in the kasB-deficient strain (Fig. 2d). The improvement might be interpreted as a chain effect caused by the enhanced cell permeability. These results further confirmed that the observed enhancement of sterol conversion and utilization was probably attributed to the improved cell permeability through the inactivation of KasB function.

\section{Deletion of $k a s B$ changed the composition of cell wall mycolic acids}

Previous studies demonstrated that KasB was dispensable for normal mycobacterial growth in $M$. marinum and $M$. smegmatis $[23,34]$. The KasB in $M$. neoaurum was proved to play a similar role in mycobacterial growth. The mechanism for the alternation of cell permeability with respect to the kasB deficiency in M. neoaurum remains unclear. Notably, KasB is responsible for the extension of meromycolic acid carbon chain [15]. This function indicated that the increased permeability was likely attributed to the changed KasB-responsible cell wall mycolic acid synthesis in the mutant strain. All of these promoted us to investigate the changes in the mycolic acid composition and length of the kasBdeficient M. neoaurum.

In the TLC analysis results, the polar TMM and TDM showed no obvious difference, whereas the mycolic acid methyl esters (MAMEs) displayed a slight decrease in the kasB mutant strain (Fig. 3a; Additional file 2: Fig. S3). The relative abundances of the a-MA, methoxy-MA and keto-MA were respectively $25.1 \%$, $23.5 \%$, and $51.4 \%$ in the $k a s B$ mutant strain and $23.5 \%, 22.6 \%$, and $53.9 \%$ in its parental strain (Fig. $3 \mathrm{~b}$ ). The decrease in keto-MA content was similar to the trend of the kasB-deleted M. tuberculosis [15]. Next, the keto-MA spot was purified and analyzed by MALDI-TOF MS. The spectrogram showed a changed mycolic acid length and the molecule weight of the most abundant keto-MA in $\triangle k a s B$ strain was reduced by 42 (Fig. 3c). The length of keto-MA in the kasB mutant was three carbon units shorter than that of the wild type [15]. Despite the inactivation of the $k a s B$ slightly changed the mycolate length, the cell wall 
permeability of the mutant strain was strikingly altered. As a result, the process that sterol substrates entered the cell was accelerated significantly.

\section{Loss of $k a s B$ led to a remarkable improvement in steroid intermediate productivity}

To determine the effect of altered MAMEs and permeability on the production of steroidal intermediates in the $k a s B$ mutant strain, the gene was deleted in the previously constructed 9-OHAD-producing strain $\mathrm{Mn} \Delta k s t D 1 \Delta k s t D 2 \Delta k s t D 3(\mathrm{WI})$. The growth speed of the mutant strain WI $\Delta k a s B$ was not decreased under the sterol-free culture conditions (Additional file 2: Fig. S4). In addition, the cell morphology of mutant strain was unaffected apparently (Fig. 4a). These results indicated that despite the deficiency of kasB, the stability of cellular structure could be still maintained in $M$. neoaurum. In view of the enhanced uptake of sterols resulted from the altered cell permeability, the accumulation capability of target steroids was preliminary analyzed. The vegetative cell transformation led to a remarkably increased 9-OHAD yield in the WI $\triangle$ kasB strain compared to its parental strain (Fig. 4b). The deletion of kasB increased the target steroid by $137.7 \%$ from $0.61 \mathrm{~g} / \mathrm{L}$ to $1.45 \mathrm{~g} / \mathrm{L}$ after 72 -h conversion. However, the increase precipitously declined to $28 \%$ at $96 \mathrm{~h}$, revealing that the bioconversion maybe highly depended on the sterol supply (Additional file 2: Fig. S5).

Next, a resting cell bioconversion system widely applied in the industry was used to further assess the enhancement effect of C19 steroid intermediate 9-OHAD generated by the kasB deletion (Fig. 4c). The highest increase was detected in WI $\Delta k a s B$ strain after 72 -h transformation with the production of $9.8 \mathrm{~g} / \mathrm{L}$, which was $48.5 \%$ higher than that of its parental WI strain $(6.6 \mathrm{~g} / \mathrm{L})$. Ultimately, the kasB-defected strain yielded $10.9 \mathrm{~g} / \mathrm{L}$ 9-OHAD with a molar yield of $69.5 \%$, whereas its parental strain only produced $8.9 \mathrm{~g} / \mathrm{L}$ with a molar yield of $56.7 \%$. In addition, if the bioconversion time was extended by $48 \mathrm{~h}$, the $9-\mathrm{OHAD}$ production of WI strain would increase to about $10.3 \mathrm{~g} / \mathrm{L}$, which was still lower than that of the kasB mutant strain. In other words, the modification of $k a s B$ gene shortened the conversion time by more than $33 \%$. The screened kasB stably remodeled the cell wall mycolic acid component, thus resulting in an increase of $22.5 \%$ in the production of C19 steroidal 9-OHAD.

The enhancement effect of $k a s B$ deficiency had been tested in another typical $C 22$ steroidal intermediate 4-HBC producing strain Mn $\Delta k s h A \Delta h s d 4 A \Delta k s t D 123$ (WIII) [6]. Similarly, an obvious improvement in the target intermediate was detected in the $k a s B$-deficient vegetative cell (Additional file 2: Fig. S6), indicating that the strategy of disrupting the mycolic acid synthesis might be efficient for the stable evolution towards target steroidal producer. Accordingly, the assessment of resting cells showed that the 4-HBC production in the WIII $\triangle k a s B$ strain was increased by $34.5 \%$ from $5.8 \mathrm{~g} / \mathrm{L}$ to $7.8 \mathrm{~g} / \mathrm{L}$ after 96 -h conversion (Fig. 4d). In addition, the 4-HBC yield was improved by $37.5 \%$ from $6.4 \mathrm{~g} / \mathrm{L}$ to $8.8 \mathrm{~g} / \mathrm{L}$ after $120 \mathrm{~h}$ biotransformation [28]. Thus, the modification of $k a s B$ is high effective for the self-enhancement of steroid intermediate conversion in $M$. neoaurum.

\section{Conclusions}


This study aimed to develop a gentle and stable self-excitation strategy of steroid intermediate conversion by the disruption of cell wall components in mycobacterial cells. To understand the important role of MAs in cell permeability related to the uptake of sterol substrate, the dispensable genes of MA synthesis in $M$. neoaurum were deleted respectively. The modification of $k a s B$ showed a striking increase in sterol conversion rate, indicating a meaningful change in the cell wall mycolic acids. The deficiency of the screened $k a s B$ gene significantly changed the cell wall permeability by altering the constitution of MAMEs and shortening the length of mycolic acids in the cell wall, thus resulting in an efficient selfenhancement of steroidal intermediate conversion.

\section{Declarations}

\section{Acknowledgements}

We sincerely thank T. Parish (Department of Infectious and Tropical Diseases, United Kingdom) for providing the plasmids, p2NIL and pGOAL19, and W. R. Jacobs Jr. (Howard Hughes Medical Institute) for providing the plasmids, pMV261 and pMV306.

\section{Authors' contributions}

LBX, HHL, MZ, YJL, LS and ZYX carried out the experiments. LBX and FQW analyzed the data. LBX, YXX, FQW and DZW conceived the study and reviewed the manuscript. All authors read and approved the final manuscript.

\section{Funding}

This work was supported by the Shanghai Municipal Education Commission (Class II Plateau Disciplinary Construction Program for Medical Technology of SUMHS, 2018-2020), the National Natural Science Foundation of China (Grant No. 31370080), the Training Subsidy Scheme of Young Teachers in Colleges and Universities of Shanghai (No. ZZJKYX19011) and the Hundred Teachers' Bank of Shanghai University of Medicine and Health Sciences.

\section{Availability of data and materials}

All data generated or analyzed during this study are included in this published article and its Additional files.

\section{Ethics approval and consent to participate}

Not applicable. 


\section{Consent for publication}

Not applicable.

\section{Competing interests}

The authors declare that they have no competing interests.

\section{Abbreviations}

KasB: $\beta$-ketoacyl-acyl carrier protein synthase; MA: mycolic acids; 9-OHAD: $9 a$-hydroxy-4-androstene-3,17dione; 4-HBC: 22-hydroxy-23,24-bisnorchol-4-ene-3-one; AD: androst-4-ene-3,17-dione; BD: boldenone; MAMEs-AG-PG: mycolyl-arabinogalactan-peptidoglycan; FASII: fatty acid synthase II; FDA, fluorescein diacetate; TMM: trehalose monomycolate; TDM: trehalose dimycolate; MAMEs: mycolic acid methyl esters; LB: Luria-Bertani; MM: minimal medium; HPLC: high performance liquid chromatography; GC: gas chromatography. FAS-I: fatty acid synthase l; FabD: malonyl CoA-acyl carrier protein (ACP) transacylase; FabH: $\beta$-ketoacyl-ACP synthase III; MabA: $\beta$-ketoacyl-ACP reductase; HadABC: $\beta$-hydroxyacyl-ACP dehydratase subunits $A, B$ and C; InhA: enoyl-ACP reductase; KasA: $\beta$-ketoacyl-ACP synthase 1; PcaA: proximal cyclopropanation of alpha-MAs enzyme; MmaA1-4: methyl mycolic acid synthase; CmaA2: cyclopropyl mycolic acid synthase; AccD4: propanoyl-CoA carbon dioxide ligase; AccD5: propionyl-CoA carboxylase; FadD32: long-chain-fatty-acid-AMP synthetase, Pks13: polyketide synthase.

\section{References}

1. Xiong LB. Analysis of the sterol metabolic pathway in mycobacteria and the modification of highyield steroidal pharmaceutical precursors producing strains. Ph.D. Thesis. East China University of Science and Technology, China. 2017.

2. Fernández-Cabezón L, Galán B, García JL. New insights on steroid biotechnology. Front Microbiol. 2018;9:958.

3. Donova MV, Dovbnya DV, Sukhodolskaya GV, Khomutov SM, Nikolayeva VM, Kwon I, Han K. Microbial conversion of sterol-containing soybean oil production waste. J Chem Technol Biot. 2005;80:55-60.

4. Zhao YQ, Shen YB, Ma S, Luo JM, Wei QY, Zhou HJ, Tang R, Wang M. Production of 5a-androstene-3, 17-dione from phytosterols by coexpression of 5a-reductase and glucose-6-phosphate dehydrogenase in engineered Mycobacterium neoaurum. Green Chem. 2019;21:1809-15.

5. Yao K, Xu LQ, Wang FQ, Wei DZ. Characterization and engineering of 3-ketosteroid- $\Delta^{1}$-dehydrogenase and 3-ketosteroid-9 $a$-hydroxylase in Mycobacterium neoaurum ATCC 25795 to produce $9 a$-hydroxy-4androstene-3,17-dione through the catabolism of sterols. Metab Eng. 2014;24:181-91. 
6. Xu LQ, Liu YJ, Yao K, Liu HH, Tao XY, Wang FQ, Wei DZ. Unraveling and engineering the production of 23,24-bisnorcholenic steroids in sterol metabolism. Sci Rep. 2016;6:21928.

7. Donova MV, Egorova OV. Microbial steroid transformations: current state and prospects. Appl Microbiol Biotechnol. 2012;94:1423-47.

8. Fernández-Cabezón L, Galán B, García JL. Unravelling a new catabolic pathway of C-19 steroids in Mycobacterium smegmatis. Environ Microbiol. 2018;20:1815-27.

9. Sun WJ, Wang L, Liu HH, Liu YJ, Ren YH, Wang FQ, Wei DZ. Characterization and engineering control of the effects of reactive oxygen species on the conversion of sterols to steroid synthons in Mycobacterium neoaurum. Metab Eng. 2019;56:97-110.

10. Shen YB, Wang M, Li HN, Wang YB, Luo JM. Influence of hydroxypropyl- $\beta$-cyclodextrin on phytosterol biotransformation by different strains of Mycobacterium neoaurum. J Ind Microbiol Biotechnol. 2012;39:1253-9.

11. Carvalho F, Marques MPC, Carvalho CCCRD, Cabral JMS, Fernandes P. Sitosterol bioconversion with resting cells in liquid polymer based systems. Bioresour Technol. 2009;99:4050-3.

12. Donova MV, Nikolayeva VM, Dovbnya DV, Gulevskaya SA, Suzina NE. Methyl- $\beta$-cyclodextrin alters growth,activity and cell envelope features of sterol-transforming mycobacteria. Microbiology. 2007;153:1981-92.

13. Fernandes P, Cruz A, Angelova B, Pinheiro HM, Cabral JMS. Microbial conversion of steroid compounds: recent developments. Enzyme Microb Tech. 2003;32:688-705.

14. Wipperman MF, Sampson NS, Thomas ST. Pathogen roid rage: cholesterol utilization by Mycobacterium tuberculosis. Crit Rev Biochem Mol. 2014;49:269-93.

15. Bhatt A, Fujiwara N, Bhatt K, Gurcha SS, Kremer L, Chen B, Chan J, Porcelli SA, Kobayashi K, Besra GS, Jacobs Jr. WR. Deletion of kasB in Mycobacterium tuberculosis causes loss of acid-fastness and subclinical latent tuberculosis in immunocompetent mice. P Natl Acad Sci USA. 2007;104:5157-62.

16. Grzegorzewicz AE, Pham H, Gundi VAKB, Scherman MS, North EJ, Hess T, Jones V, Gruppo V, Born SE, Korduláková J, et al. Inhibition of mycolic acid transport across the Mycobacterium tuberculosis plasma membrane. Nat Chem Biol. 2012;8:334-41.

17. Marrakchi H, Lanéelle MA, Daffé M. Mycolic acids: structures, biosynthesis, and beyond. Chem Biol. 2014;21:67-85.

18. Zimhony $\mathrm{O}$, Vilchèze $\mathrm{C}$, Jacobs WR. Characterization of Mycobacterium smegmatis expressing the Mycobacterium tuberculosis fatty acid synthase I (fas1) gene. J Bacteriol. 2004;186:4051-5.

19. Griffin JE, Gawronski JD, Dejesus MA, loerger TR, Akerley BJ, Sassetti CM. High-resolution phenotypic profiling defines genes essential for mycobacterial growth and cholesterol catabolism. PLoS Path. 2011; $7:$ e1002251.

20. Vilchèze $C$, Morbidoni HR, Weisbrod TR, Iwamoto H, Kuo M, Sacchettini JC, Jacobs WR. Inactivation of the inhA-encoded fatty acid synthase II (FASII) enoyl-acyl carrier protein reductase induces accumulation of the FASI end products and cell lysis of Mycobacterium smegmatis. J Bacteriol. 2000;182:4059-67. 
21. Parish T, Roberts G, Laval F, Schaeffer M, Daffé M, Ken DC. Functional complementation of the essential gene fabG1 of Mycobacterium tuberculosis by Mycobacterium smegmatis fabG but not Escherichia colifabG. J Bacteriol. 2007;189:3721-8.

22. Sacco E, Covarrubias AS, O'Hare HM, Carroll P, Eynard N, Jones TA, Parish T, Daffé M, Backbro K, Quémard A. The missing piece of the type II fatty acid synthase system from Mycobacterium tuberculosis. P Natl Acad Sci USA. 2007;104:14628-33.

23. Bhatt A, Kremer L, Dai AZ, Sacchettini JC, Jacobs WR. Conditional depletion of KasA, a key enzyme of mycolic acid biosynthesis, leads to mycobacterial cell lysis. J Bacteriol. 2005;187:7596-606.

24. Zhang RJ, Liu XC, Wang YS, Han YC, Sun JS, Shi JP, Zhang BG. Identification, function, and application of 3-ketosteroid $\Delta^{1}$-dehydrogenase isozymes in Mycobacterium neoaurum DSM 1381 for the production of steroidic synthons. Microb Cell Fact. 2018;17:77.

25. Li ZJ, Hong PH, Da YY, Li LK, Stephanopoulos G. Metabolic engineering of Escherichia coli for the production of L-malate from xylose. Metab Eng. 2018;48:25-32.

26. Liu D, Mao Z, Guo J, Wei L, Ma H, Tang YJ, Chen T, Wang Z, Zhao X. Construction, model-based analysis and characterization of a promoter library for fine-tuned gene expression in Bacillus subtilis. ACS Synth Biol. 2018;7:1785-97.

27. Zhou L, Ding Q, Jiang GZ, Liu ZN, Wang HY, Zhao GR. Chromosome engineering of Escherichia coli for constitutive production of salvianic acid A. Microb Cell Fact. 2017;16:84.

28. Xiong LB, Liu HH, Xu LQ, Sun WJ, Wang FQ, Wei DZ. Improving the production of 22-hydroxy-23,24bisnorchol-4-ene-3-one from sterols in Mycobacterium neoaurum by increasing cell permeability and modifying multiple genes. Microb Cell Fact. 2017;16:89.

29. Xiong LB, Sun WJ, Liu YJ, Wang FQ, Wei DZ. Enhancement of 9a-hydroxy-4-androstene-3,17-dione production from soybean phytosterols by deficiency of a regulated intramembrane proteolysis metalloprotease in Mycobacterium neoaurum. J Agric Food Chem. 2017;65:10520-5.

30. Gao XQ, Feng JX, Qiang H, Wei DZ, Wang XD. Investigation of factors affecting biotransformation of phytosterols to 9-hydroxyandrost-4-ene-3,-17-dione based on the HP- $\beta$-CD-resting cells reaction system. Biocatal Biotransfor. 2014;32:343-7.

31. Xiong LB, Liu HH, Xu LQ, Wei DZ, Wang FQ. Role identification and application of SigD in the transformation of soybean phytosterol to $9 a$-hydroxy-4-androstene-3,17-dione in Mycobacterium neoaurum. J Agric Food Chem. 2017;65:626-31.

32. Shen YB, Wang M, Zhang LT, Ma YH, Ma B, Zheng Y, Liu H, Luo JM. Effects of hydroxypropyl- $\beta$ cyclodextrin on cell growth, activity, and integrity of steroid-transforming Arthrobacter simplex and Mycobacterium sp. Appl Microbiol Biotechnol. 2011;90:1995-2003.

33. Nguyen L, Chinnapapagari S, Thompson CJ. FbpA-Dependent biosynthesis of trehalose dimycolate is required for the intrinsic multidrug resistance, cell wall structure, and colonial morphology of Mycobacterium smegmatis. J Bacteriol. 2005;187:6603-11.

34. Gao LY, Laval F, Lawson EH, Groger RK, Woodruff A, Morisaki JH, Cox JS, Daffe M, Brown EJ. Requirement for kasB in Mycobacterium mycolic acid biosynthesis, cell wall impermeability and 
intracellular survival: implications for therapy. Mol Microbiol. 2003;49:1547-63.

\section{Tables}

\section{Table 1 Strains used in this study}

\begin{tabular}{|c|c|c|}
\hline Name & Description & Source \\
\hline E. coli DH5 $\alpha$ & E. coli strain for cloning & $\begin{array}{l}\text { TIANGEN } \\
\text { CO., LTD. }\end{array}$ \\
\hline $\begin{array}{l}\text { M. } \\
\text { neoaurum ATCC }\end{array}$ & Wild type strain, the starting strain & ATCC \\
\hline \multicolumn{3}{|l|}{$25795(\mathrm{Mn})$} \\
\hline $\mathrm{Mn} \Delta \mathrm{kstD1}$ & kstD1 deleted in $M$. neoaurum ATCC 25795 & [5] \\
\hline WI & $\begin{array}{l}\text { kstD1, kstD2 and kstD3 deleted in } M . \text { neoaurum ATCC 25795, 9- } \\
\text { OHAD producing strain }\end{array}$ & [5] \\
\hline WI $\Delta$ had $A$ & hadA deleted in WI strain & This study \\
\hline WI $\Delta$ hadC & hadC deleted in WI strain & This study \\
\hline WI $\Delta$ kas $B$ & kas $B$ deleted in WI strain & This study \\
\hline WI $\triangle m m a A N$ & mmaAN (N represents $1,2,3,4)$ deleted in WI strain & This study \\
\hline WI $\Delta p k s 13$ & pks13 deleted in WI strain & This study \\
\hline $\operatorname{Mn} \Delta k a s B$ & kasB deleted in $M$. neoaurum ATCC 25795 & This study \\
\hline $\operatorname{Mn} \Delta k a s B+k a s B$ & kas $B$ complemented in $\mathrm{Mn} \Delta$ kas $B$ strain & This study \\
\hline $\mathrm{WI} \Delta k a s B+k a s B$ & kasB complemented in WI $\Delta$ kasB strain & This study \\
\hline WIII & $\begin{array}{l}\text { kshA1, kshA2, hsd4A, kstD1, kstD2 and kstD3 deleted in } M . \\
\text { neoaurum ATCC } 25795,4 \text {-HBC producing strain }\end{array}$ & [ 6] \\
\hline WIII $\Delta k a s B$ & kas $B$ deleted in WIII strain & This study \\
\hline
\end{tabular}

Figures 

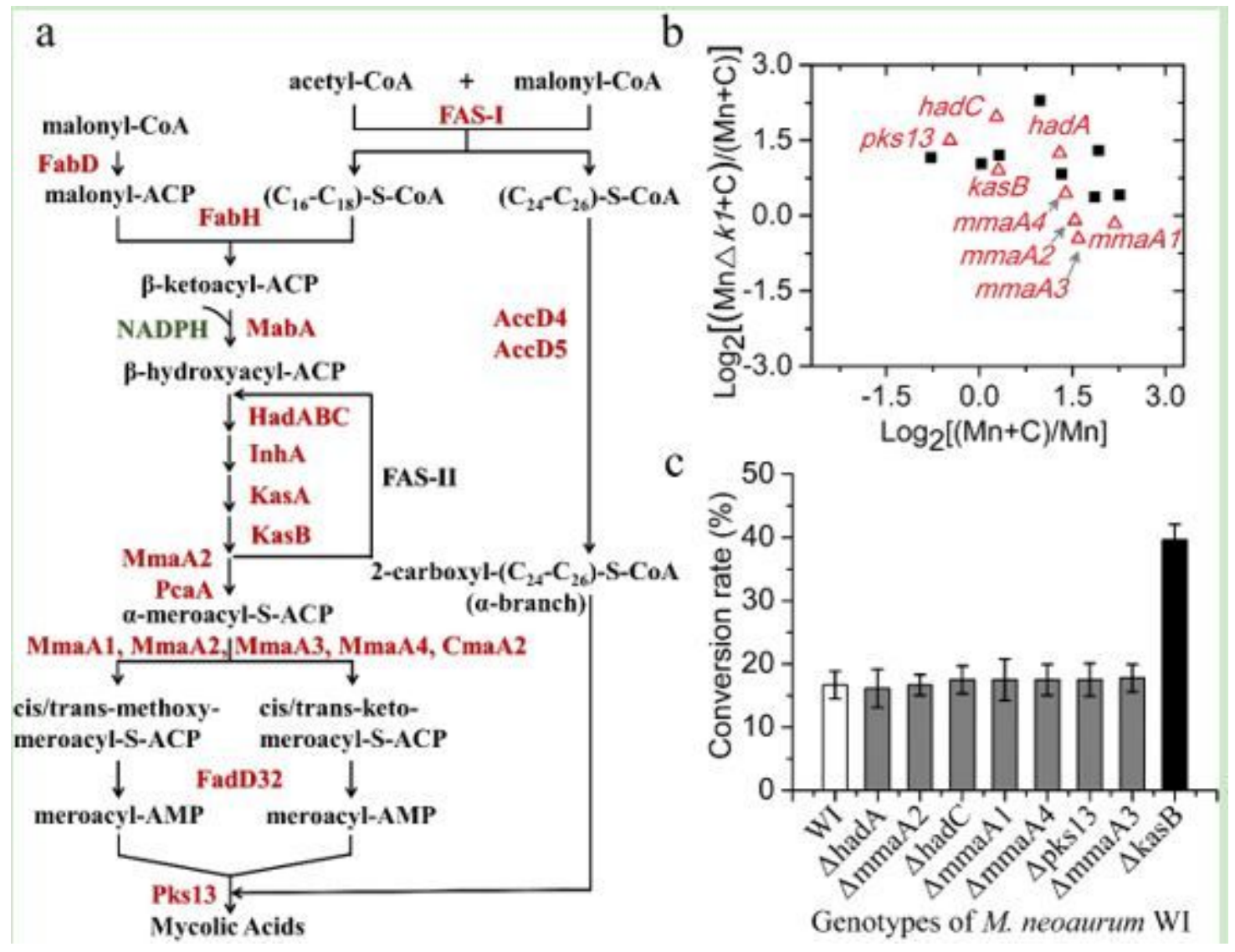

Figure 1

Rational disruption of the mycolic acid synthesis disturbed the sterol conversion. a Profile of the mycolic acid synthesis pathway in mycobacteria cells [17]. FAS-I, fatty acid synthase I; FabD, malonyl CoA-acyl carrier protein (ACP) transacylase; FabH, $\beta$-ketoacyl-ACP synthase III; MabA, $\beta$-ketoacyl-ACP reductase; HadABC, $\beta$-hydroxyacyl-ACP dehydratase subunits $A, B$ and $C$; InhA, enoyl-ACP reductase; KasA, $\beta$ ketoacyl-ACP synthase 1 ; KasB, $\beta$-ketoacyl-ACP synthase 2; PcaA, proximal cyclopropanation of alphaMAs enzyme; MmaA1-4, methyl mycolic acid synthase; CmaA2, cyclopropyl mycolic acid synthase; AccD4, propanoyl-CoA carbon dioxide ligase; AccD5, propionyl-CoA carboxylase; FadD32, long-chainfatty-acid-AMP synthetase, Pks13, polyketide synthase. b Transcription changes in the dispensable genes involved in mycolic acid synthesis. All data indicate log2 fold change ratio of the gene expression. Mn, the wild type $\mathrm{M}$. neoaurum was cultured in $\mathrm{MYC} / 02$ medium. $\mathrm{Mn}+\mathrm{C}$, the wild type strain was cultivated in the presence of phytosterol. Mn $\Delta \mathrm{kstD} 1+\mathrm{C}$, the primary 9-OHAD-producing strain Mn $\Delta \mathrm{kstD} 1$ was cultured in MYC/02 medium with phytosterol addition. Data were from two independent analyzes. $\mathrm{c}$ The alternation of sterol conversion rate caused by the targeted gene disruption in 72 hours sample time. Data represent the mean standard deviation of three measurements. 
a

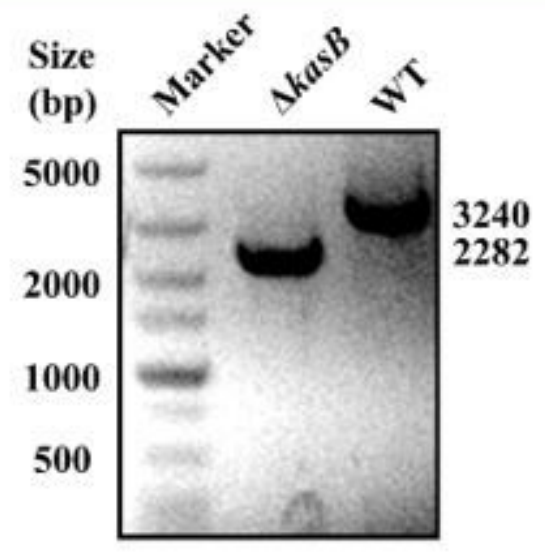

b

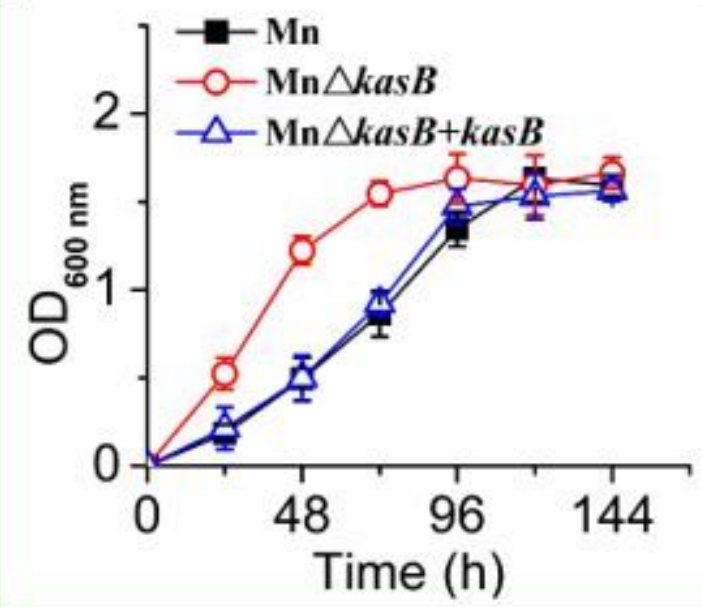

C

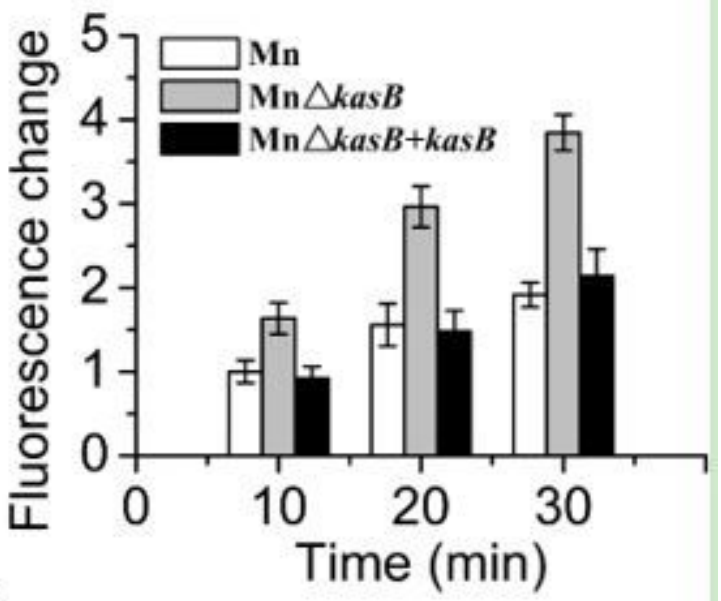

d

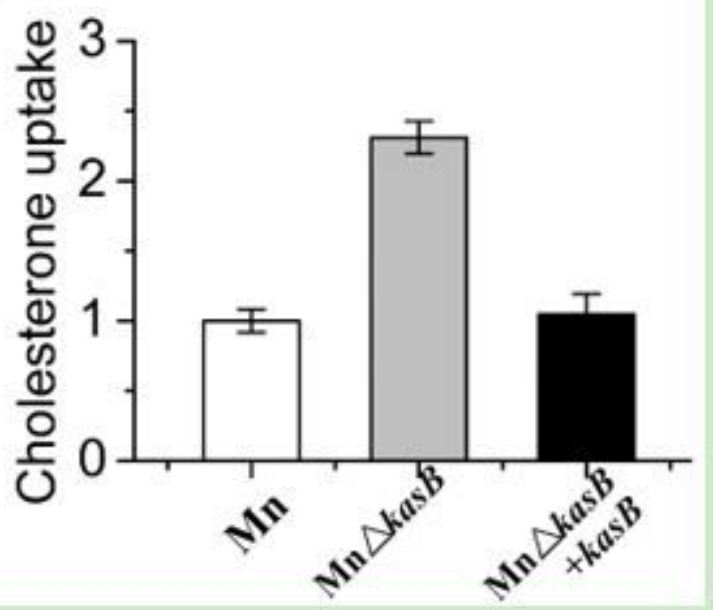

Figure 2

Effects of the deficiency of kasB on the cell permeability. a Validation of allelic replacement at the kasB locus in M. neoaurum ATCC 25795. The wild type (WT) 3,240-bp was replaced by a 2282-bp fragment ligate with the upstream and downstream homologous arm. $b$ Growth characteristic of the kasB mutant strain. The wide-type M. neoaurum (Mn), the kasB-deficient strain (Mn $\Delta$ kasB) and the kasBcomplemented strain (MnAkasB+kasB) were cultured in MM containing $1.0 \mathrm{~g} / \mathrm{L}$ cholesterol. c Determination of the cell permeability in the kasB mutant strain. The cells were stained with FDA, incubated at $32{ }^{\circ} \mathrm{C}$ for $10 \mathrm{~min}$, and analyzed by a fluorescence spectrophotometer. $\mathrm{d}$ Influences of the deficiency of kasB on the steroid (cholest-4-en-3-one) uptake. The cholest-4-en-3-one entering the cells after 12-h growth in MM containing $1.0 \mathrm{~g} / \mathrm{L}$ cholest-4-en-3-one was determined. 


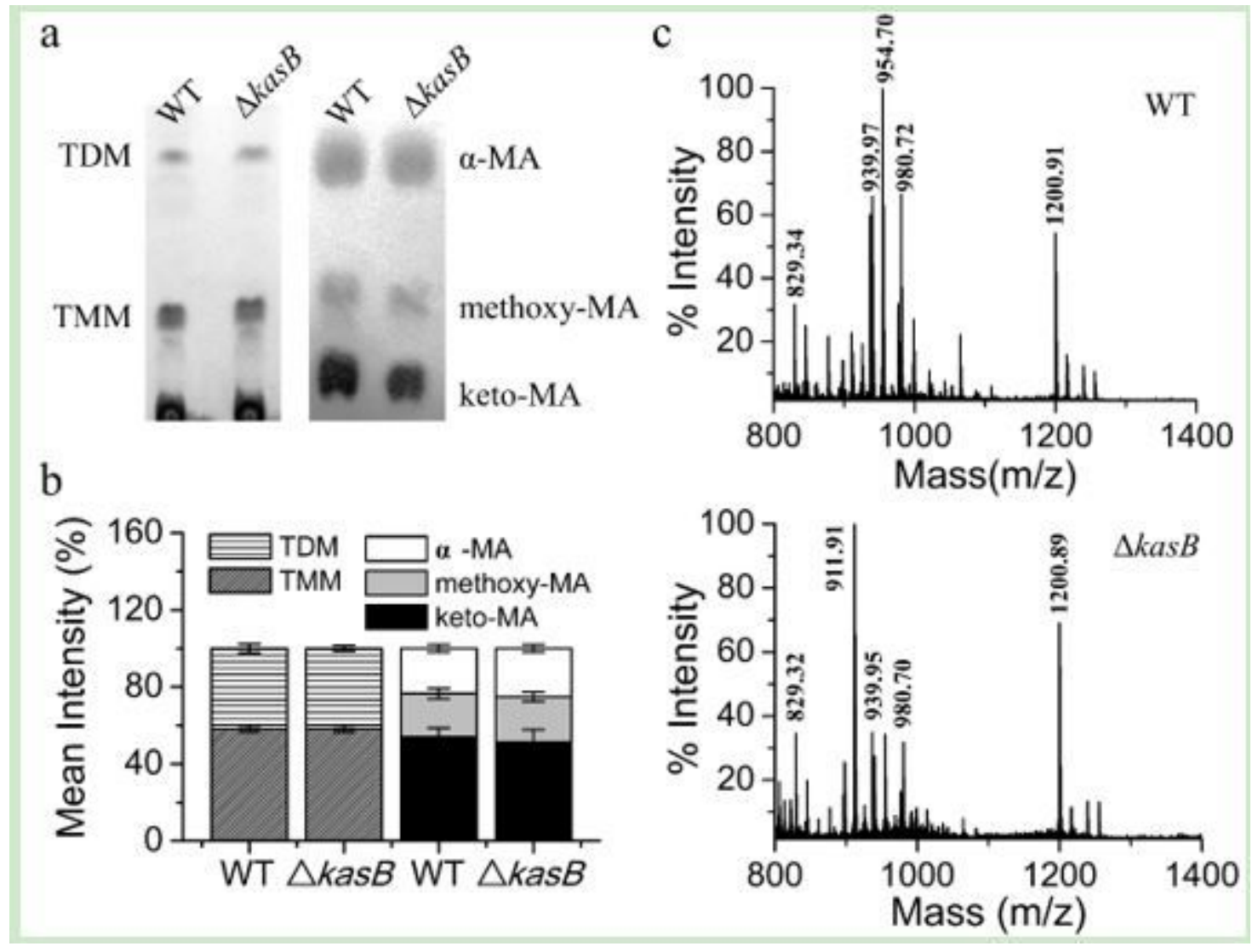

Figure 3

Effects of kasB on the component of cell wall mycolic acids in M. neoaurum. a The strain carrying the wild type (WT) or the deficient kasB ( $\triangle \mathrm{kasB}$ ) strain was cultivated in the presence of $1.0 \mathrm{~g} / \mathrm{L}$ phytosterols. MAMEs (a-, methoxy- and keto- forms of mycolic acids) were isolated from M. neoaurum cells. TLC plates were revealed with cupric sulfate ( $10 \% \mathrm{w} / \mathrm{v}$ in an $8 \% \mathrm{v} / \mathrm{v}$ phosphoric acid solution). b Relative intensity of the mycolate compared to the total mycolates. The deletion of kasB caused a slight disturbance in $\mathrm{M}$. neoaurum. c MALDI-TOF mass spectra of the keto-MAMEs of M. neoaurum strains. 


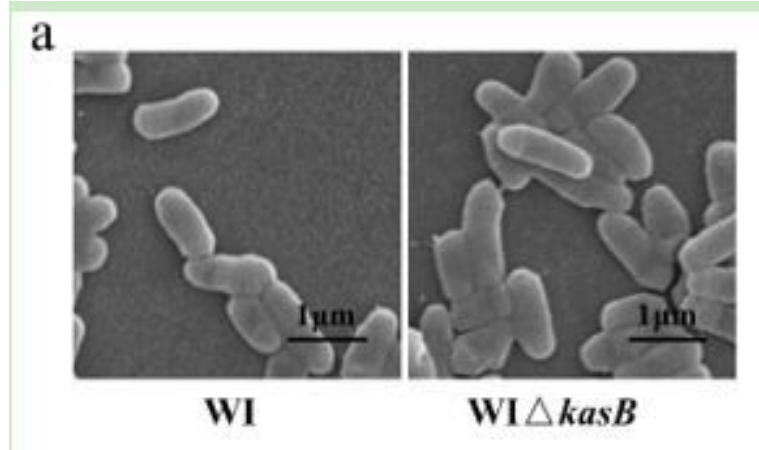

$\mathrm{b}$
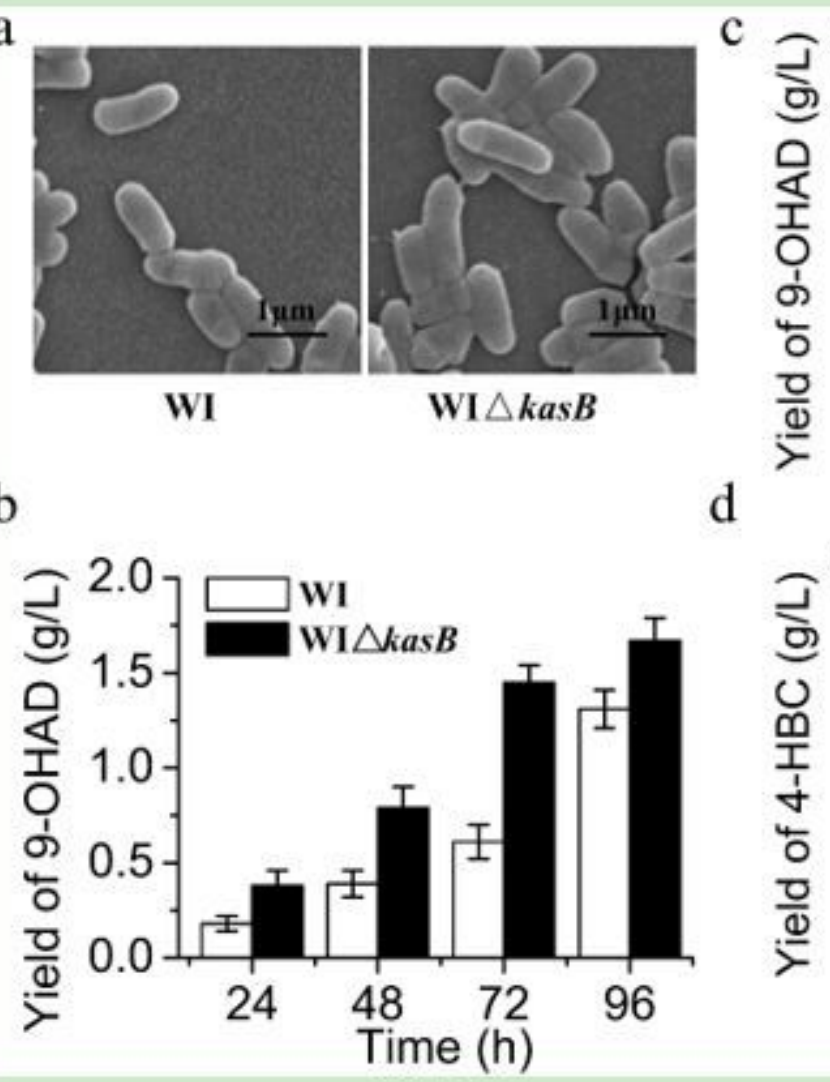

d

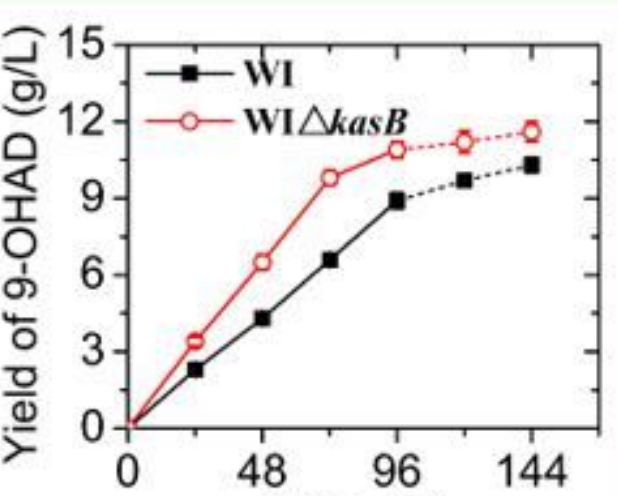

Time (h)

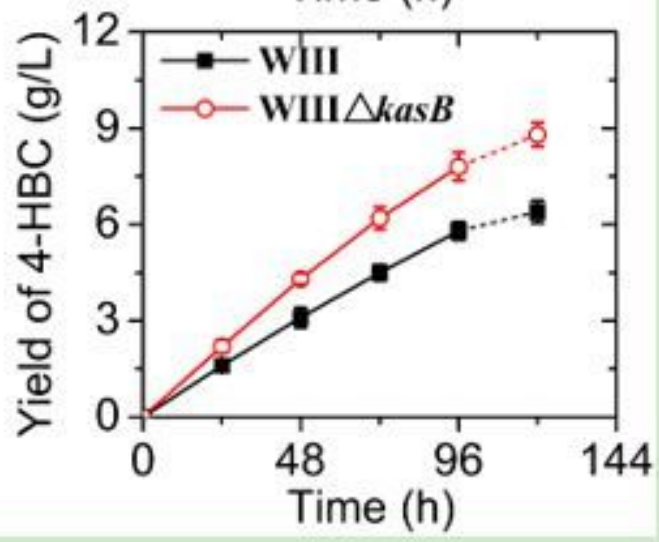

Figure 4

Enhancement of the 9-OHAD productivity in M. neoaurum. a Cell morphologies of the engineered mutant strains revealed by a scanning electron microscope. b Assessment of 9-OHAD yield for the deficiency of kasB. Quantitative analyses of the 9-OHAD yield in the vegetative cell transformation of $2 \mathrm{~g} / \mathrm{L}$ phytosterols. c Determination of the C19 intermediate 9-OHAD productivity in the constructed 9-OHADproducing strain WI $\Delta \mathrm{kasB}$ by a resting cell system containing $20 \mathrm{~g} / \mathrm{L}$ of phytosterols. $d$ Measurement of the $\mathrm{C} 22$ intermediate $4-\mathrm{HBC}$ productivity in the engineered producer WIII $\Delta$ kasB by resting cell conversion in the presence of $20 \mathrm{~g} / \mathrm{L}$ phytosterols.

\section{Supplementary Files}

This is a list of supplementary files associated with this preprint. Click to download.

- Additionalfile1.docx

- Additionalfile2.docx 